\title{
HOW TO DISTINGUISH AND TRANSLATE SYNONYMOUS ENGLISH LEGAL TERMS ${ }^{1}$
}

\author{
Vladimir Ozyumenko \\ Associate Prof., Dr, Peoples' Friendship University of Russia (RUDN University), RUSSIA, \\ E-mail ozyumenko-vi@rudn.university, vladimir@ozyumenko.ru
}

\begin{abstract}
The article deals with the problem of teaching and learning legal terminology at the lessons of professional English for law students. It focuses on the lexical-semantic group LAWYER, characterized by a high nominative density in English and includes several scores of lexemes, nominating professionals representing defendants' interests in courts, e.g., attorney, barrister, solicitor, advocate, counsel, legal practitioner, litigator, jurist, procurator, trial lawyer, counselor, counselor-at-law etc. This fact poses considerable difficulty for Russian ESL learners as in Russian there is only one term with the corresponding meaning advokat. The article pursues the goal to explore semantic and functional differences in legal terms under consideration and suggests some techniques for their teaching and learning. The study aims to answer the questions: (1) how to differentiate the English legal terms, and (2) how to translate them. The data were taken from various sources: dictionaries, legal documents, and Internet resources. Comparative, semantic and cultural analysis was implemented. The findings show that due to the developed system of the English law (Common law) and its long history English possesses a considerable set of terms denoting the lawyers representing clients' interests which do not have their lexical counterparts in Russian. The paper argues that to distinguish between English synonymous legal terms and find their translation equivalents the following aspects should be taken into consideration: (1) cultural variability of the English language, i.e. a national variety of English, (2) functional varieties of lawyers in the system of law; (3) functions of lawyers within the framework of a case; (4) status differences of lawyers; (5) frequency of usage of the term discussed; (6) its stylistic characteristic (official - colloquial - slang). The findings can be used in the teaching of Legal English to law students, be applied in Lexicography, as well as contribute to the study of pluricentric languages.
\end{abstract}

Keywords: Pluricentricity, legal English, lawyer, terminological variability, translation equivalent, Russian, ESL

\footnotetext{
${ }^{1}$ This publication has been supported by the RUDN University Strategic Academic Leadership Program. Some of the ideas of this study are also discussed in: Ozyumenko, V. (2014). English equivalents of the Russian word 'advokat'. Bulletin of the Peoples' Friendship University of Russia. Russian and foreign languages. Methods of teaching. 4. 114119. (In Russ.), Ozyumenko, V. (2020b). Addressing a judge in national varieties of English. Russian Journal of Linguistics 24 (1). 137-157. DOI: 10.22363/2687-0088-2020-24-1-137-157.
} 


\section{INTRODUCTION}

The World Englishes (WE) paradigm (e.g. Bolton 2020, Kachru and Smith 1985, Proshina 2014, Proshina and Nelson 2020, Smith and Forman 1997), "has radically challenged the traditional views on the Empire's linguistic dominance, flipped sociolinguistic ideas, and drastically changed pedagogical beliefs that had found their way into English language teaching and learning" (Proshina and Nelson 2020: 526) including teaching translation. It has convincingly showed that English is not a monolithic and homogeneous language anymore; being pluricentric, it has differentiated into a great number of varieties - world Englishes (cf. Proshina and Nelson 2020: 526). The ignorance of this fact creates problems in translation studies and practices, and not only.

As numerous research prove translation studies have become an interdisciplinary science which uses data from neighboring disciplines (e.g., Gambier 2016, 2019; Pym, Shlesinger and Jettmarová 2006, Sdobnikov 2019, Snell-Hornby 2006). For both theory and practice of translation, including professional translation, the main problem is the problem of equivalence (for more references see e.g. Panou 2013, Pym 2009). A translation equivalent is a "corresponding word or expression in another language" ${ }^{2}$, in other words it is a correctly found correspondence. Equivalents are translational matches with minimal contextual dependence; they can be complete and partial, absolute and relative. Full lexical equivalents are words that fully cover the meaning of the whole word, rather than one of its meanings (Retsker 2004: 15). However, scholars in translation studies as well as cultural semantics have found that there are practically no complete lexical equivalents (e.g. Latyshev and Semenov 2008, Gladkova and Larina 2018 a,b, Wierrzbicka 1996 and many others). Among the few equivalents that are considered complete equivalents, geographic names and terms are usually named. However, even terms do not always appear to be complete equivalents. As it has been showed in previous studies (see Chilingaryan, Larina and Ozyumenko 2016, 2017; Ozyumenko 2014, 2020a) though legal discourse is supposed to be clear, precise and unambiguous, in legal terminology there are obvious signs of cultural variability that can be observed not only in different languages, but also in varieties of the same language (Ozyumenko 2020a: 137).

The study deals with the problem of teaching and learning legal terminology at the lessons of professional English for law students. It explores semantic and functional differences in English legal terms, nominating professionals representing defendants' interests in courts which do not have their lexical counterparts in Russian where the only word advokat exists. This fact creates serious difficulties in translation ${ }^{3}$. The paper suggests some techniques for their ESL teaching and learning.

\section{DATA AND METHODOLOGY}

The study focuses on the lexical-semantic group LAWYER, characterized by a high nominative density in English. This group includes several scores of lexemes, nominating professionals representing defendants' interests in courts, e.g., attorney, barrister, solicitor, advocate, counsel, legal practitioner, litigator, jurist, procurator, trial lawyer, counselor, counselor-at-law etc. This fact poses considerable difficulty for ESL learners as in Russian there is only one term advokat which covers all the English terms. The data were taken from various sources: dictionaries, legal documents, newspapers and Internet resources. Comparative, semantic and cultural analysis was implemented to explore semantic and functional differences in legal terms.

The study aims to answer the questions: (1) how to differentiate the English legal terms, and (2) how to translate them into Russian.

\section{ANALYSIS OF THE RESULTS}

The findings have shown that in Russian, the word advokat has a large semantic volume and covers almost the entire field of legal defense. The New Comprehensive Russian-English Dictionary provides 5 main options for translating this word into English: lawyer; attorney Am. solicitor Br., barrister Br., counselor Am. The given labels indicate their territorial differentiation. However, an analysis of English-Russian dictionaries ${ }^{4}$ showed that in English there are many more terms which designate persons performing certain functions in the system of law, related to the practice of law and correspond to the Russian word advokat in at least one

\footnotetext{
${ }^{2}$ Glossary of Linguistic Terms

3 The question of how to designate the profession of a lawyer in the English version of business cards is widely discussed on the Internet.

${ }^{4}$ See e.g. New Comprehensive English-Russian Dictionary
} 
of the meanings, e.g. legal practitioner, litigator, advocate, counsel, jurist; procurator; trial lawyer, counselorat-law and others. They differ in function, powers, status and other characteristics.

As the conducted analysis showed, there are several sources of plurality of English legal terminology in general and terms denoting lawyers in particular. One of them is conditioned by varieties of English language and differences in national legal systems. The jurisdiction of England and Wales generated most of legal terms. Here the legal profession is split between solicitors and barristers. A lawyer usually holds only one of the two titles. Legal professionals practicing in countries of the British Commonwealth bear the same titles, but with some peculiarities. For example, a lawyer may practice both as a barrister and solicitor in Canada, New Zealand and some states of Australia where this distinction is fused.

The territorial factor is quite salient, since these terms have their own specificities in different varieties of English. Further I will analyse territorial English translation equivalents of the Russian word advokat and also specify some of their functional characteristics.

In British English, the most common terms are lawyer, barrister and solicitor, which refer to lawyers who differ in their function in the legal defense system. All three terms are covered by the broader term legal practitioner. Lawyer is the most general term for representing one of the parties in a court of law or giving advice on legal issues. ("Lawyer' is the most general word for talking about someone who either represents people in a court of law or advises people about legal problems" ${ }^{\prime 5}$ ). They can deal with both a wide range of cases and specialize in a specific area of law (family, corporate, criminal, etc.). Solicitor is a lawyer who provides legal advice, practices law, prepares legal documents. Lawyers in this category work in private companies, government agencies, law firms. They can represent the interests of the parties in the courts, but only in the lower courts. A lawyer who has the right to appear in the higher courts is called a barrister. He undergoes additional professional training. Another term is used to refer to him in court is counsel which is used as a rule in the third person:

(1) Counsel is asked to advise (Reverso) (rather than You are asked to advise)

(2) I would ask counsel to refrain from interrupting me (Reverso) (rather than Could you please refrain from interrupting me).

Dictionaries define the difference between these two lawyer titles as follows: "In the UK, a lawyer who speaks in court is called barrister, and a lawyer, who mainly works in an office is called a solicitor, and these two types of lawyer have different training" ". 'There are other differences between the two: Unlike solicitors, barristers cannot usually be employed directly by clients but are instructed by solicitors; solicitors normally form partnerships with other solicitors and work in offices with support staff, barristers cannot form partnerships but must act as sole traders with unlimited liability (Brown and Rice 2007: 26). Barristers work with clients indirectly through solicitors, they do not form legal entities and bear full responsibility. There is also a collective word the Bar which is translated into Russian as advokaty (pl) ${ }^{7}$.

Legal system of Scotland has its own set of titles. It might be due to the influence of civil law system. Legal profession in this jurisdiction is represented by solicitors and advocates. The term advocate is used as a legal title (office) only in Scotland", though in its broader meaning ("An advocate is a lawyer who speaks in favour of someone or defends them in a court of law"9) it can be seen in all Common Law jurisdictions.

The jurisdiction of Ireland contributed to development of legal titles by introducing the term Senior Counsel (S.C.) instead of Queens Counsel (Q.C.). It is explained by the fact that the British monarch is no longer head of state and the reference to the Queen has become irrelevant. This example was followed by Australia and New Zeeland ${ }^{10}$.

In the United States, the term lawyer can correspond to attorney, which means almost the same thing, but this term is more formal ("A lawyer in the US is also sometimes referred to as an attorney, especially in

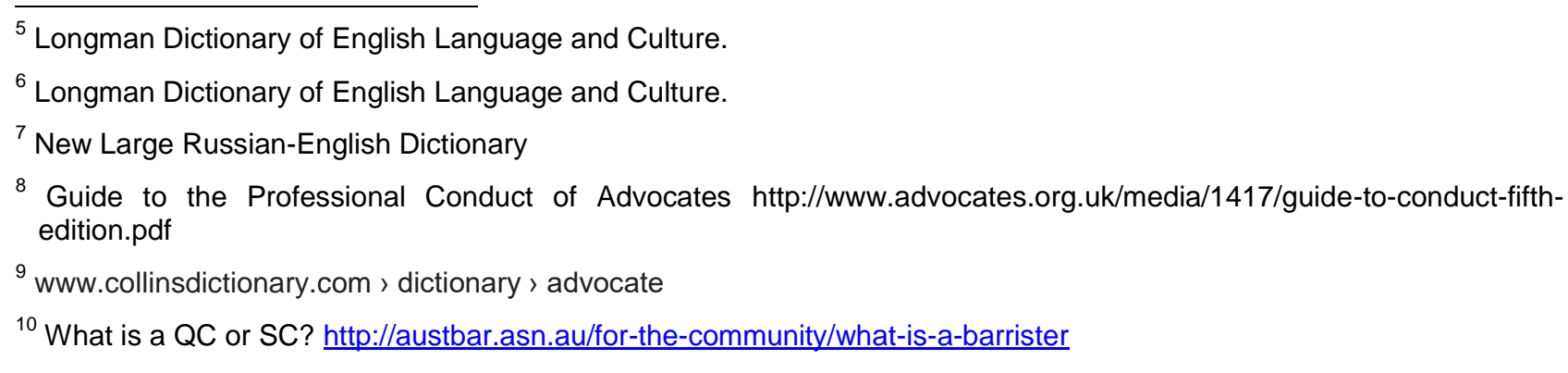


formal speech or official letters"11). The term counselor is also used, especially in court, where it is also an appeal or appellate attorney which mean a lawyer appearing in an appellate court. In American practice, there is no role differences between those who appear in court (trial lawyers, or litigators) and those who work exclusively in offices, just as there is no difference between lawyers who appear in courts of different instances, like solicitor vs. barrister in the UK. However, the term attorney at large is encountered, referring to those who can appear in any court. In writing communication, the term esquire is additionally used. It is added to attorney's name in an abbreviated form as Esq., e. g. "John Smith, Esq." and renders respect to the professional name (Hickey 2008).

In my findings there are other culture specific terms in the national varieties of English: writer (ScotE), jurist (AmE), squire (AmE), vakeel (IE), counselor-at-law (IrE) and others ${ }^{12}$.

In addition, there are terms denoting various functions of lawyers in the legal system, i.e., terms that differentiate lawyers within the framework of a court case: litigator is a lawyer representing the plaintiff or defendant in court; co-counsel is an additional attorney, most often representing another firm. They may also contain an indication of status differences. e.g. senior counsel (leading counsel), leader in lawsuit (the main lawyer of a party), pleader (the youngest of two lawyers of one party), etc.

The findings show that in $\mathrm{BrE}$ in contrast to AmE there are numerous terms that indicate the status differences of lawyers. E.g., among those who are called barristers, there are junior barrister, senior barrister, Queen's Council (QC) or King's Council (KC) (depending on who is the monarch, the king or queen), etc. Barrister, who has no practice is called a briefless barrister. After working for 10-15 years, a junior barrister can apply for the position (title) of a senior barrister or Queen's Council (QC). There is also an inner barrister, a high-ranking barrister who appears in court within a barrier separating judges from defendants, and an utter (outer) barrister, an outside barrister. The term Queen's Council refers to a highlevel barrister who handles serious cases in the higher courts. There is also a sergeant, or sergeant-at-law (a lawyer of the highest category), a junior counsel (a lawyer who is below the rank of QC). In a number of British Commonwealth countries, the title of senior counsel is found, corresponding to the title of Queen's Council. At a lower status position there are legal assistant, associate lawyer, sub-advocate, third chair. All of them are translated into Russian as помощник адвоката 'assistant lawyer'.

There are also peripheral groups of the lexical-semantic field LAWYER which include highly specialized and rarely used terms which are also translated into Russian as advokat, e.g. King's (Queen's) Proctor; Crown counsel $(\mathrm{BrE})^{13}$, circuiteer (a county mobile court lawyer); avowee (a lawyer representing the interests of a church parish in courts); proctor (a lawyer at special and ecclesiastical courts), apprentice (a lawyer who has worked for less than 16 years) ${ }^{14}$, etc.

Some words translated into Russian as advokat refer to colloquial vocabulary or slang and have corresponding dictionary labels. Among them there are tongue, lip brief $(\mathrm{BrE})$, mouthpiece (AmE) (criminal lawyer):

(3) How much do you pay your lip? ${ }^{15}$

(4) The judge told the skinhead that it was only his brief's eloquence that had saved him from prison ${ }^{16}$

Most of them have a pronounced negative connotation: pettifogger (lit.: 'small trader', also means 'fraudster'); law-monger (lit.: 'a lawyer conducting dubious cases'); legal beagle (lit. 'legal greyhound', a rogue lawyer); hedge lawyer (an underground lawyer); ambulance chaser (lit.: 'one who chases an ambulance'); also capper (a lawyer who imposes his services on victims of accidents, in AmE also a member of the gang). In American slang, lawyers are also called patch, or patcher, which also means a moron, a jester.

Another difficulty in teaching and translating legal terms stems from the fact that they are not always unambiguous. Some them are polysemantic and have several meanings, they name different legal

\footnotetext{
${ }^{11}$ Macmillan English Dictionary for Advanced Learners

${ }^{12}$ New Comprehensive English-Russian Dictionary, MULTITRAN

${ }^{13}$ New Russian-English Law Dictionary

${ }^{14}$ MULTITRAN

${ }^{15}$ MULTITRAN

${ }^{16}$ MULTITRAN
} 
professions and positions, i.e. intersect with other lexical and sematic fields. The term lawyer is a good example. In English-Russian dictionaries it is translated into Russian by the terms which mean 'jurist', 'advokat', 'company lawyer', 'legal adviser'; 'international lawyer'; attorney is translated as advokat, 'a justice officer'; and 'a prosecutor'; Attorney General is 'a senior official of the justice authorities' (who is a member of the cabinet of ministers), 'the Minister of Justice' and 'the Attorney General' (in the USA); 'Chief State Attorney' (in the USA) ${ }^{17}$

However, the finding revealed the fact that dictionaries do not always pay attention to specific characteristics of a lawyer and solely limit to translation. E.g. in my material there is a number of lexemes and collocations which are translated into Russian as 'advokat', but do not contain any differentiating features, which made it difficult to understand them: attendant, associate, man of law, member of the bar, legal adviser, legal profession member etc.

\section{DISCUSSION AND CONCLUSIONS}

Our findings show that the lexical-semantic group LAWYER is characterized by a high nominative density in English. For the Russian word advokat, English offers numerous translation options that nominate various differential territorial, functional and stylistic characteristics of a lawyer. In other words, English in contrast to Russian appear to have a rich repertoire of lexemes which nominate diverse shades of the members of this professional community and their characteristics. This fact can be explained by the developed system of English law and its long history. Thus, there is a 'vector correspondence' (Sternin 2006), when a unit of the source language corresponds to several units of the target language (Sternin 2006: 23).

The revealed lexical and semantic inconsistencies create certain translation difficulties, which might be solved in different ways depending on the source and target language. When translating from Russian into English, the method of concretization should be used, when translating from English into Russian, the method of generalization might be applied. To translate the Russian word advokat into English, the word lawyer seems to be the most reliable option. But in order to find a more accurate match, a wide context is needed, including education, status of the lawyer, his functions, position, etc. Since, as it has been shown, these terms vary in national varieties of English, it is important to take into account the cultural context. Only the context allows us to choose the most appropriate equivalent.

The paper argues that to distinguish between English synonymous legal terms and find their translation equivalents the following aspects should be taken into consideration: (1) cultural variability of the English language, i.e. a national variety of English, (2) functional varieties of lawyers in the system of law; (3) functions of lawyers within the framework of a case; (4) status differences of lawyers; (5) frequency of usage of the term discussed; (6) its stylistic characteristic (official - colloquial - slang). The constructivist approach which supposes the active participation of students and their creativity (see e.g. Kurteš, Larina \& Ozyumenko 2017, Ozyumenko 2020b) also seems useful.

It is worth noting, that due to the international cooperation in the legal sphere and the need to convey professional differences embedded in English lexemes Russian has borrowed some of English terms, which are used in Cyrillic transliteration and are already fixed in some dictionaries ${ }^{18}$ e.g. coлисumop 'solicitor', барристер 'barrister', атторней 'attorney'. It can be assumed that this process will continue.

The analysis showed that each variety of English serves the corresponding legal system and contributes to enriching legal vocabulary. However, dictionary focus on educational learner needs seems to ignore the today's range and depth of the socio-cultural functions of global English (see Lovtsevich and Sokolov 2020: 703). Raising awareness of the diversity of Englishes is of unquestionable value in language teaching and learning and in translation and interpretation (Proshina and Nelson 2020: 531). Knowing distinctive features of other varieties, will make intervarietal communication, including intervarietal translation, easier and more efficient. The results can contribute to the study of pluricentric languages and find application in lexicography, as well as in the teaching of legal English to law students.

\section{ACKNOWLEDGMENTS}

This publication has been supported by the RUDN University Strategic Academic Leadership Program.

\footnotetext{
${ }^{17}$ New Large Russian-English Dictionary

${ }^{18}$ See e.g. New Large Russian-English Dictionary, MULTITRAN
} 


\section{REFERENCE LIST}

Bolton, Kingsley. (2020). World Englishes: Current debates and future directions. In Cecil L. Nelson, Zoya G. Proshina \& Daniel R. Davis (eds.), The Handbook of World Englishes. $2^{\text {nd }}$ edn., 743-760. Hoboken, NJ: Wiley-Blackwell.

Chilingaryan K., Larina T., \& Ozyumenko V. (2016). Ambiguity of culture-bound terms in legal English and Russian. In SGEM2016 Conference Proceedings. 1 (1), 529-540. DOI: 10.5593/SGEMSOCIAL2016/B11/S03.068 http://sgemsocial.org/ssgemlib/spip.php?article2271

Chilingaryan K., Larina T., \& Ozyumenko V. (2017) "Judge" and "sudya" in the English and Russian languages: in search for terminological adequacy. Proceedings of INTCESS 2017 4th International Conference on Education and Social Sciences, 6-8 February 2017- Istanbul, Turkey. ISBN: 978-60564453-9-2, 369 - 376. http://www.ocerint.org/intcess 17 epublication/abstracts/a19.html

Gambier, Y. (2016). Rapid and Radical Changes in Translation and Translation Studies. International Journal of Communication. Issue 10, 887-906.

Gambier, Y. (2019). Impact of technology on Translation and Translation Studies. Russian Journal of Linguistics, 23 (2), 344-361. doi: 10.22363/2312-9182-2019-23-2-344-361.

Gladkova, A. \& Larina, T. (2018a). Anna Wierzbicka, Words and The World. Russian Journal of Linguistics, 22 (3), 499-520. doi: 10.22363/2312-9182-2018-22-3-499-520

Gladkova, A. \& Larina, T. (2018b). Anna Wierzbicka, Language, Culture and Communication. Russian Journal of Linguistics, 22 (4), 717 -748. DOI: 10.22363/2312-9182-2018-22-4-717-748.

Hickey, R. (2008). The Official Guide to Names, Titles, and Forms of Address Honor \& Respect. Protocol School of Washington,

Kachru, B. B. \& Smith, L. E. (1985). Editorial. World Englishes 4 (2), 209-212.

Kurteš S., Larina T., \& Ozyumenko V. (2017) Constructivist approach to intercultural communication teaching and learning. EDULEARN17 Proceedings. 9th International Conference on Education and New Learning Technologies. Barcelona, Spain. 3-5 July, 2017, 591-59 doi:10.21125/edulearn.2017.1127

Latyshev L.K., Semenov A.L. (2008). Translation: Theory, practice and teaching methods. 4th ed. Moscow: Publishing Center "Academy".

Lovtsevich, G. N. \& Sokolov, A. A. (2020). World Englishes and learner lexicography: View from the Expanding Circle. Russian Journal of Linguistics 24 (3). 703-721. DOI: 10.22363/2687-0088-2020-24-3703-721

Ozyumenko, V. (2014). English equivalents of the Russian word 'advokat'. Bulletin of the Peoples' Friendship University of Russia. Russian and Foreign Languages. Methods of Teaching. 4, 114-119.

Ozyumenko, V. (2020a). Addressing a judge in national varieties of English. Russian Journal of Linguistics 24 (1), 137-157. DOI: 10.22363/2687-0088-2020-24-1-137-157.

Ozyumenko, V. (2020b). 'Spiritual' or 'Espionage' centre: How to develop pragma-discursive competence reading a newspaper text. In Abstracts \& Proceedings of INTCESS 2020- 7th International Conference on Education and Social Sciences, 20-22 January 2020- Dubai, UAE. 903 - 911.

Panou, D. (2013). Equivalence in Translation Theories: A Critical Evaluation Theory and Practice in Language Studies, 3 (1), 1-6.

Proshina, Zoya G. (2014). Language revolution behind the cultural curtain. World Englishes 33 (1), 1-8.

Proshina, Zoya G. \& Cecil L. Nelson. (2020). Varieties of English and Kachru's Expanding Circle. Russian Journal of Linguistics 24 (3), 523-550. DOI: 10.22363/2687-0088-2020-24-3-523-550

Pym, A. (2009). Natural and directional equivalence in theories of translation. In Gambier, Y. \& van Doorslaer, L. (eds.). The Metalanguage of Translation, 81-104. Amsterdam: John Ben-jamins.

Pym A., (2010) Exploring Translation Theories. London. Routledge,

Pym A., Shlesinger, M. \& Z. Jettmarová (eds.) (2006). Sociocultural aspects of translating and interpreting. Amsterdam: John Benjamins. 
Retsker Ya. I. (2004). Translation theory and translation practice. Moscow: RValent (In Russ.)

Sdobnikov, V. (2019). Translation Studies Today: Old Problems and New Challenges. Russian Journal of Linguistics, 23 (2), 295-327. doi: 10.22363/2312-9182-2019-23-2-295-327.

Smith, Larry E. \& Michael L. Forman (eds.). (1997). World Englishes 2000. Honolulu: University of Hawaii Press.

Snell-Hornby, M. (2006). The Turns of Translation Studies. New Paradigms or Shifting View-points? Amsterdam/Philadelphia: John Benjamins.

Sternin I.A.(2006). Contrastive linguistics. Problems of theory and research methods. Moscow: East-West. (In Russ.)

Wierzbicka, A.(1996) Semantics, Primes and Universals. Oxford: Oxford University Press.

\section{Dictionaries and Internet Resources:}

Glossary of Linguistic Terms https://glossary.sil.org/term/translational-equivalence\#

Guide to the Professional Conduct of Advocates http://www.advocates.org.uk/media/1417/guide-to-conductfifth-edition.pdf

Longman Dictionary of Contemporary English. Longman, 1995.

Longman Dictionary of English Language and Culture. Addison Wesley Longman, 1998.

Macmillan English Dictionary for Advanced Learners: International Student Edition. Macmillan Publishers Limited, 2002.

MULTITRAN http://www.multitran.ru

New Comprehensive English-Russian Dictionary: In 3 volumes / Y.D. Apresyan, E.M. Mednikova, A.V. Petrova and others. Moscow.: Russian language, 1999.

New Large Russian-English Dictionary / D.I. Ermolovich, T.M. Krasavina; under the general guidance of prof. DI. Ermolovich. 3rd ed., Stereotype. Moscow.: Russian language - Media, 2008.

New Russian-English Law Dictionary / Borisenko I.I., Saenko V.V. About 23,000 terms. Moscow.: RUSSO, 2002.

What is a QC or SC? http://austbar.asn.au/for-the-community/what-is-a-barrister 